\title{
Aplikasi Penginderaan Jauh dan EPA-SWMM untuk Simulasi Debit Banjir Akibat Perubahan Lahan Sub DAS Banjaran
}

\author{
Moh. Lutfi Ariwibowo *, Suripin, Pronoto Samto Atmojo \\ Departemen Teknik Sipil, Fakultas Teknik, Universitas Diponegoro, \\ Jl. Prof. Soedarto, SH, Kampus Undip Tembalang, Semarang, Indonesia 50275
}

\begin{abstract}
Abstrak
Tataguna lahan di Sub Daerah Aliran Sungai (DAS) Banjaran telah mengalami perubahan yang cukup tinggi selama kurun waktu 1995 sampai 2001. Lahan sawah berkurang 1.759,28 hektar menjadi 1.603,97 hektar, tegalan berkurang 289,54 hektar menjadi 283,32 hektar dan permukiman bertambah 1.284,36 hektar menjadi 1.445,88 hektar. Alih fungsi lahan ini mengakibatkan banjir sering terjadi. Beberapa kali Sungai Banjaran meluap menyebabkan banjir di permukiman dan ruas jalan. Kajian pengaruh perubahan lahan terhadap debit banjir perlu dilakukan sehingga peningkatan debit banjir dapat dikendalikan.Tujuan penelitian ini menganalisis debit banjir secara periodik sesuai dengan perubahan tata guna lahan yang terjadi berdasarkan data hidrologi dan parameter DAS. Perhitungan debit banjir dilakukan dengan kalibrasi Environmental Protection Agency - Storm Water Management Model( EPA-SWMM), yaitu metode Hidrograf Observasi (debit terukur) yang dikalibrasi dengan metode Nash. Analisis perubahan lahan menggunakan peta tataguna lahan tahun 2005, Citra Satelit Quick Bird tahun 2010 dan 2014 yang berbasis Geography Information System (GIS). Penggunaan citra satelit resolusi tinggi Quick Bird memenuhi ketepatan dalam menentukan daerah impervious dan pervious sertamorfometri DAS sebagai parameter utama dalam input EPA-SWMM. Model yang telah terkalibrasi digunakan untuk simulasi debit rencana sampai periode ulang 50 tahun.Perubahan lahan selama tahun 2005-2014 permukiman meningkat sebesar 10,98 ha (2,39\%), luas hutan menurun 1,67 ha (0,07\%), telah mengakibatkan kenaikan debit banjir Q2 sampai Q50 tahun. Besarnya debit dan kenaikannya berturut-turut sebagai berikut : Q2 tahun sebesar 3,08 $\mathrm{m}^{3} / \mathrm{dtk}(2,16 \%)$, Q5 tahun sebesar $3,5 \mathrm{~m}^{3} / \mathrm{dtk}(1,87 \%)$, Q10 tahun sebesar 3,72 $\mathrm{m}^{3} / \mathrm{dtk}(1,7 \%)$, Q25 tahun sebesar 3,94 $\mathrm{m}^{3} / \mathrm{dtk}(1,60 \%)$ dan Q50 tahun sebesar $4,13 \mathrm{~m}^{3} / d t k(1,50 \%)$. Volume banjir terjadi peningkatan yakni: $Q_{2}$ tahun sebesar $0,57 \%\left(10.10^{6}\right)$ liter, Q5 tahun sebesar 0,45\% (12.10 ) liter, Q10 tahun sebesar 0,42\%

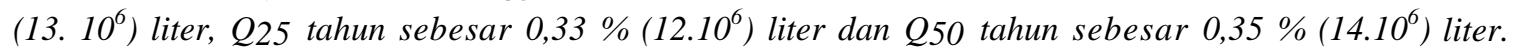
Usaha pengendalian banjir pada periode ulang 50 tahun (Q50) yang disimulasikan mampu menurunkan debit banjir antara lain : penegakkan hukum sebesar 14,43 $\mathrm{m}^{3} / \mathrm{dtk}(5 \%)$, embung sebesar $20,9 \mathrm{~m}^{3} / \mathrm{dtk}$ $(7,1 \%)$ dan sumur resapan sebesar $31,18 \mathrm{~m}^{3} / \mathrm{dtk}(10,73 \%)$. Skenario RTRW sebesar $26,3 \mathrm{~m}^{3} / \mathrm{dtk}$ (9,05\%), kombinasi sumur resapan dan penegakan hukum sebesar 45,92 $\mathrm{m}^{3} / \mathrm{dtk}(15,81 \%)$ dan kombinasi embung dan penegakan hukum sebesar 40,58 $\mathrm{m}^{3} / \mathrm{dtk}(13,97 \%)$. Dari hasil simulasi diperoleh pembuatan sumur resapan, kombinasi sumur resapan dan penegakan hukum, kombinasi embung dan penegakan hukum mampu menurunkan debit banjir sampai pada $Q 25$.
\end{abstract}

Kata kunci: Citra Quick Bird; Debit Banjir; Embung; EPA-SWMM; Sumur Resapan

\begin{abstract}
[Title: The application of Remote Sensing and EPA-SWMM for flood discharge due to land use change at Banjaran Sub Watershed] There has been drastical change on sub watershed land use in Banjaran district since 1995 to 2001. Rice fields dwindled from 1.759,28 to 1.603,97 hectares, moors decreased from 289,54 to 283,32 hectares and settlements increased from 1.284,36 to 1.445,88 hectares. This land use change had caused frequent flood. Banjaran's river has overflowed, causing flood in the road and the settlement areas. Thus a study on the impact of land use change on flood discharge need to be done in order to control the increasing flood discharge. The aim of this study is to make a periodic
\end{abstract}

\footnotetext{
${ }^{*}$ Penulis Korespondensi.

E-mail: lutfi_wibowo78@yahoo.co.id
} 


\section{Teknik, 38 (2), 2017, 120}

analyzes based on land use change and hydrologic data as well as sub watershed parameter which is flood discharge was measured with EPA-SWMM calibration. This method combines Observed Hydrograph (measured discharge) calibrated with Nash method. Analysis of land use change were using land use map of 2005, Quickbird satellite images of 2010 and 2014. The use of high resolution Quick Bird satellite image was able to perfectly determine impervious and pervious areas as well as the sub watershed morphometric as the main parameter in EPA-SWMM input. The calibrated model was used to simulate future flood discharge up to 50 years to come. The result of the study showed that during 2005 to is decreased around 1,67 ha (0,07\%), had caused the rise of flood discharge $Q_{2}$ to $Q 50$ years. The volume and the rise of the discharge were as follows: $Q_{2}$ years $3,08 \mathrm{~m}^{3} / \mathrm{sec}(2,16 \%), Q_{5}$ years $3,5 \mathrm{~m}^{3} / \mathrm{sec}(1,87$

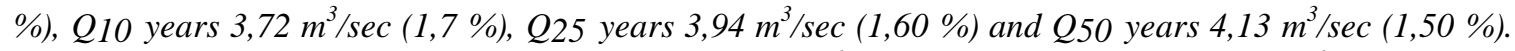
Flood volume were increasing: $Q 2$ years $0,57 \%\left(10.10^{6}\right)$ litters, Q5 years $0,45 \%\left(12.10^{6}\right)$ litters, Q10 years $0,42 \%\left(13.10^{6}\right)$ litters, Q25 years $0,33 \%\left(12.10^{6}\right)$ litters and Q50 years $0,35 \%\left(14.10^{6}\right)$ litters. The simulated control of flood return of 50 years $(250)$ that was able to decrease flood discharge were: law enforcement $14,43 \mathrm{~m}^{3} / \mathrm{sec}(5 \%)$, reservoir $20,9 \mathrm{~m}^{3} / \mathrm{sec} \quad(7,1 \%)$, infiltration wells 31,18 $\mathrm{m}^{3} / \mathrm{sec}(10,73 \%)$, spatial planning scenario $26,3 \mathrm{~m}^{3} / \mathrm{sec}(9,05 \%)$, combination of infiltration wells and law enforcement $45,92 \mathrm{~m}^{3} / \mathrm{sec}(15,81 \%)$ whereas combination of reservoirs and law enforcement around $40,58 \mathrm{~m}^{3} / \mathrm{sec}(13,97 \%)$. The result of the simulation shows that the use of infiltration wells, the combination of infiltration wells and law enforcements, the combination of reservoirs and law enforcements was able to decrease flood discharge up to $Q 25$.

Keywords: EPA-SWMM; Flood Discharge; Infiltration Well; Quick Bird Image; Reservoirs

\section{Pendahuluan}

DAS Banjaran, yang terletak di Kabupaten Banyumas, mengalami perubahan tataguna lahan pada kurun waktu tahun 1995 hingga 2001. Lahan sawah yang semula berkisar 1.759,28 hektar menyusut menjadi 1.603,97 hektar, sementara tegalan yang semula 289,54 hektar, berkurang menjadi 283,32 hektar, sedangkan permukiman yang semula mencakup 1.284,36 hektar bertambah menjadi 1.445,88 hektar (Suroso, Susanto, 2006). Perubahan ini tidak lepas dari pemanfaatan lahan di pusat Kota Purwokerto. Sebagian besar lahan pada pusat kota sudah dimanfaatkan sebagai kawasan perdagangan dan jasa, pemerintahan, serta sebagian kecil permukiman. Adanya keterbatasan lahan serta ditambah pula dengan tingginya harga lahan pada pusat kota, mengakibatkan pembangunan Kota Purwokerto mengalami penyebaran ke segala arah. (Dienaulie, 2011). Ini juga yang menyebabkan penurunan jumlah luas lahan hutan rakyat dan negara di Kabupaten Banyumas. Pada tahun 2009 luas lahan hutan rakyat dan negara menurun sebesar 2,71\% dari total luas Kabupaten Banyumas atau sebesar 3.597,77 Ha. Menurunnya luas hutan rakyat dan negara ini dibarengi dengan meningkatnya lahan pekarangan/pemukiman (Abadi Purwa Citra, 2009).

Perubahan tata guna lahan ini berdampak pada banjir yang terjadi di wilayah tersebut. saat hujan lebat mengguyur Purwokerto dan sekitarnya, luapan sungai Banjaran dan anak sungainya beberapa kali menyebabkan banjir. Sungai Kalibener yang merupakan anak Sungai Banjaran meluap dan membanjiri sejumlah kelurahan dan desa diantaranya Kelurahan Karangpucung dan Teluk Kecamatan Purwokerto Selatan. Air banjir merendam 120 unit Perumahan (www.pikiranrakyat.com, tanggal 04 Juni 2009).

Perubahan tata guna lahan yang ada menyebabkan peningkatan aliran permukaan dan potensi banjir. Untuk mengantisipasi hal ini maka perlu adanya kajian tentang pengaruh perubahan tata guna lahan tersebut yang dilakukan secara periodik terhadap debit banjir yang ada di Sub DAS Banjaran. Kajian ini juga hendak melihat kemungkinan adanya ketidaksesuaian antara tataguna lahan dan RTRW Kabupaten Banyumas.

Analisa untuk mengetahui seberapa besar pengaruh perubahan lahan terhadap fluktuasi debit banjir dilakukan dengan menggunakan alat bantu ArcGIS. ArcGIS diharapkan dapat mempermudah analisis spasial (ruang) terhadap pola tata guna lahan yang ada. Selain menggunakan ArcGIS, kajian ini juga menggunakan Environmental Protection Agency - Storm Water Management Model (EPA-SWMM) untuk membantu dalam analisa debit rencana. Program EPA-SWMM dipilih karena dengan EPA-SWMM, kondisi yang terjadi di lapangan dapat dimodelkan dengan memasukan parameter-parameter yang tercatat pada kondisi sesungguhnya.

Penelitian ini dimaksudkan untuk menganalisa pengaruh perubahan lahan terhadap debit banjir, sehingga dapat digunakan untuk merumuskan fasilitas pengelolaan debit untuk mengendalikan peningkatan debit banjir pada Sub DAS Banjaran Kabupaten Banyumas. Diharapkan dengan penelitian ini diketahui perubahan lahan pada periode waktu yang diteliti $(2005,2010$, dan 2014); debit banjir yang terjadi setiap periode yang diteliti; debit banjir observasi (Automatic Water Level Record) dengan debit simulasi; prediksi debit banjir dimasa mendatang sampai 


\section{Teknik, 38 (2), 2017, 121}

50 tahun; serta diketahui pengaruh perubahan lahan terhadap debit banjir dan menganalisa pengendalian/usaha-usaha pengelolaan debit banjir.

\section{Metode Penelitian}

\subsection{Pengumpulan Data}

Metode pengumpulan data digunakan dalam penelitian ini adalah observasi langsung serta studi dokumentasi melalui pengumpulan data dari dokumendokumen yang tersedia atau terkait.

\subsubsection{Data Primer}

Data-data primer dikumpulkan melalui proses observasi langsung, pengukuran, cek lapangan di lokasi penelitian. Adapun data-data tersebut meliputi :

a. Morfometri sungai: lebar sungai, kedalaman sungai, tinggi saluran sisi tanggul, kekasaran sungai, lebar dasar sungai, kondisi sungai.

b. Kondisi tata guna lahan: jenis penutup lahan/penggunaan lahan, kedap dan tidaknya lahan, tataguna lahan khususnya untuk cek lapangan dalam rangka penyusunan peta penggunaan lahan, koordinat sungai.

\subsubsection{Data Sekunder}

Pengumpulan data sekunder dilakukan dengan cara mengumpulkan data melalui dokumen-dokumen yang tersedia pada dinas/instansi pengelola. Data-data tersebut meliputi :

1. Peta topografi, peta landuse/penggunaan lahan, citra satelit, pada Badan Perencanaan Pembangunan Daerah Kabupaten Banyumas. Adapun peta penggunaan lahan tahun 2005, citra satelit quick bird untuk landuse 2008 dan 2015 diperoleh dari Badan Perencanaan Pembangunan Daerah (Bappeda) Kabupaten Banyumas.

2. Data penggunaan lahan, data jenis tanah, dan kemiringan lereng.

3. Data curah hujan, data debit Sungai Banjaran pada Dinas Sumberdaya air dan Bina Marga Kabupaten Banyumas, Balai Sumber Daya Air Serayu Citanduy, dan Badan Meteorologi, Klimatologi dan Geofisika.

4. Data laporan hasil penelitian/kajian, jurnal penilitian.

\subsection{Analisa Debit Banjir}

Analisa debit puncak dalam penelitian ini adalah dengan perhitungan metode Hidrograf Observasi/terukur dan EPA-SWMM. Hidrograf observasi dihasilkan dari Automatic Water Level Record (AWLR) di Stasiun Kober.

\subsection{Kalibrasi Model}

Kriteria penampilan model atau yang lebih dikenal dengan kalibrasi model adalah salah satu cara mengkaji model untuk mengetahui parameter-parameter yang dipakai model dapat diterapkan pada kondisi lapangan atau kondisi rencana. Adapun metode untuk menentukan criteria penampilan atau kalibrasi model terhadap hasil debit puncak dari Hidrograf Observasi (Qp Observasi) sebagai berikut :

Nash adalah metode kalibrasi dengan membandingkan kuadrat selisih debit hasil simulasi dan debit hasil pengamatan dengan kuadrat selisih debit pengamatan dan rata-rata debit pengamatan. Metode Nash mensyaratkan pemodelan dikatakan valid jika nilainya mendekati satu (Tabel 1) (Moriasi, et al., 2007).

Nash $=1-\frac{\sum i(Q \operatorname{sim}-Q \circ b s)^{2}}{\sum i(Q \circ b s-\underline{0} \circ b s)^{2}}$

dimana :

$\mathrm{Q}_{\text {sim }}=$ debit hasil simulasi $\left(\mathrm{m}^{3} / \mathrm{dt}\right)$

$\mathrm{Q}_{\text {obs }}=$ debit hasil Qp HS. Alami (m $\left.{ }^{3} / \mathrm{dt}\right)$

$\overline{\mathrm{Q}}_{\mathrm{obs}}^{\mathrm{obs}}=$ rata-rata debit pengamatan di lapangan

$\left(\mathrm{m}^{3} / \mathrm{dt}\right)$

Tabel 1. Kriteria dalam kalibrasi Nash

\begin{tabular}{cll}
\hline No & Performance Rating & \multicolumn{1}{c}{ Kriteria Nash } \\
\hline 1 & Very good & $0,75<$ Nash $\leq 1,00$ \\
2 & Good & $0,65<$ Nash $\leq 0,75$ \\
3 & Satisfactory & $0,50<$ Nash $\leq 0,65$ \\
4 & Unsatisfactory & Nash $\leq 5,00$ \\
\hline
\end{tabular}

Sumber : Moriasi et al., 2007

\subsection{Analisa Perubahan Penggunaan Lahan}

Data penggunaan lahan yang digunakan pada penelitian ini adalah penggunaan lahan tahun 2005 yang berasal bersumber peta penggunaan lahan tahun 2005 dari Bappeda Kabupaten Banyumas, sedangkan data penggunaan lahan tahun 2010 dan tahun 2014 diperoleh dari pemrosesan citra quick bird untuk perolehan penggunaan lahan tahun 2010 dan tahun 2014 dengan bantuan software ArcGIS 10. Dari penggunaan lahan tahun 2005, 2010 dan tahun 2014 dapat diketahui perubahan lahan dan perubahan alih fungsi lahan di daerah penelitian. Sehingga dapat dibandingkan perubahan tersebut dari kurun waktu 2005 sampai dengan 2014 (Tabel 2).

\section{Hasil dan Pembahasan}

\subsection{Analisa Tataguna Lahan}

Proses overlay menghasilkan Peta Tataguna Lahan Sub DAS Banjaran tahun 2005 (Gambar 1). Koreksi, baik koreksi geometri, radiometri maupun penajaman citra atas citra quick bird untuk periode 2010 dapat dilihat pada Gambar 2, sedangkan koreksi geometri, radiometri serta penajaman citra quick bird untuk periode tahun 2014 dapat dilihat pada Gambar 3. 
Teknik, 38 (2), 2017, 122

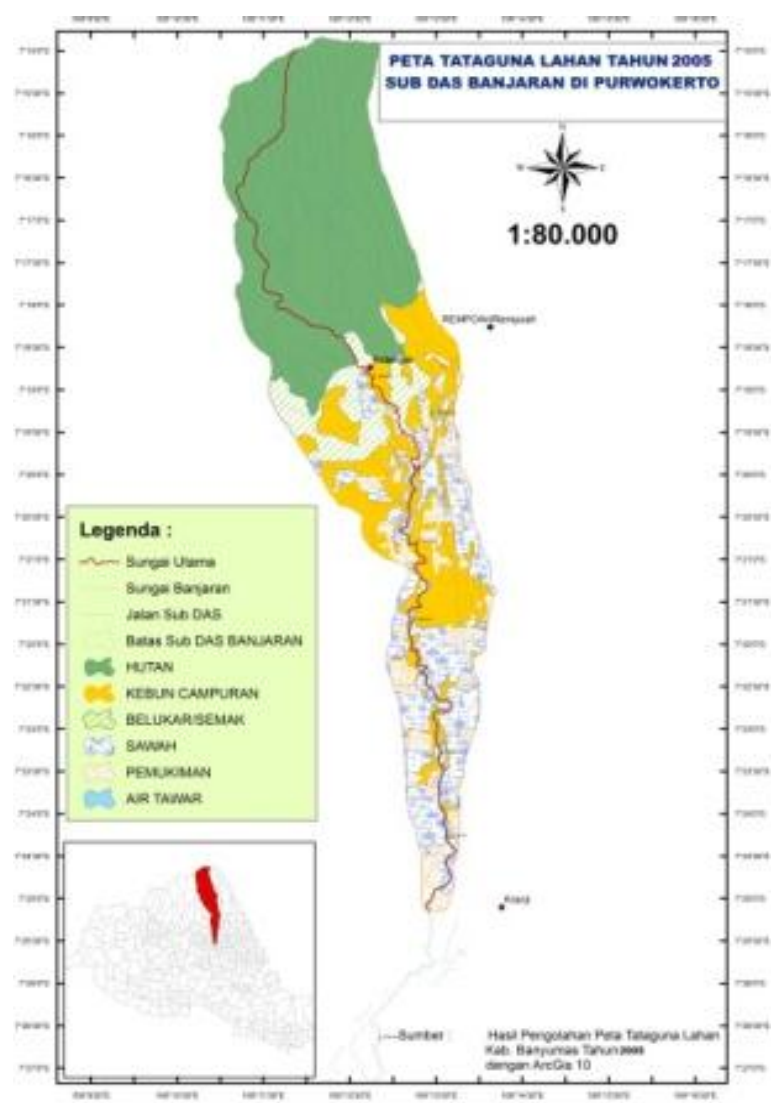

Gambar 1. Peta tataguna lahan tahun 2005

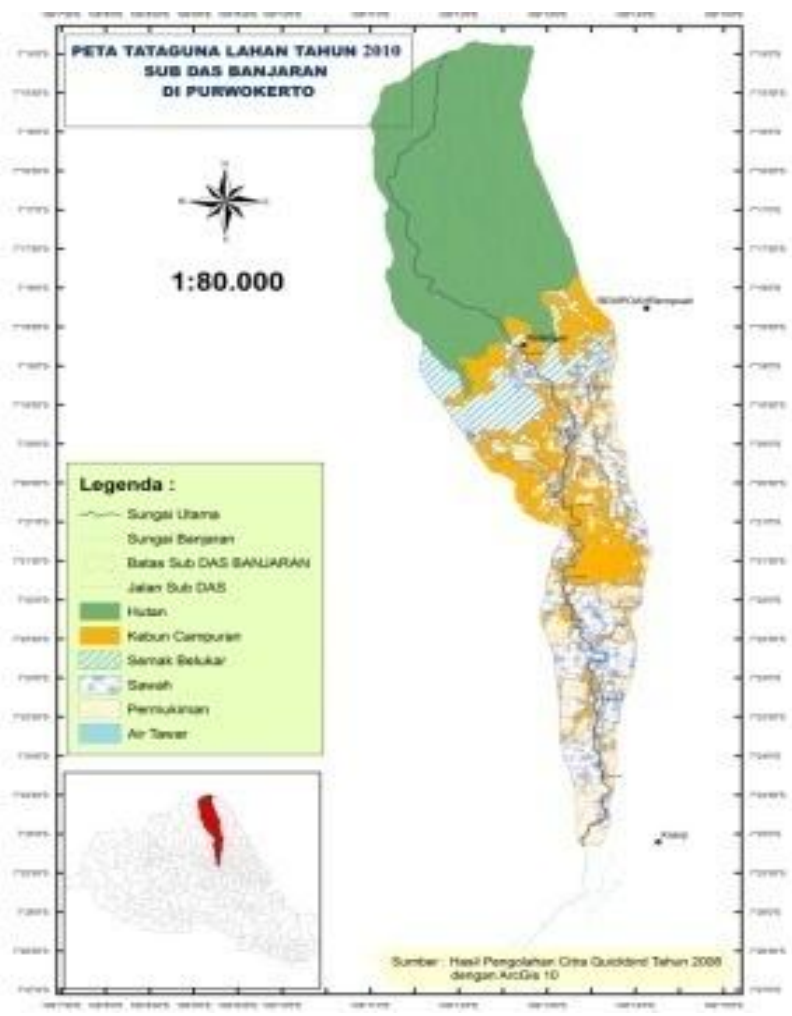

Gambar 2. Peta tataguna lahan tahun 2010

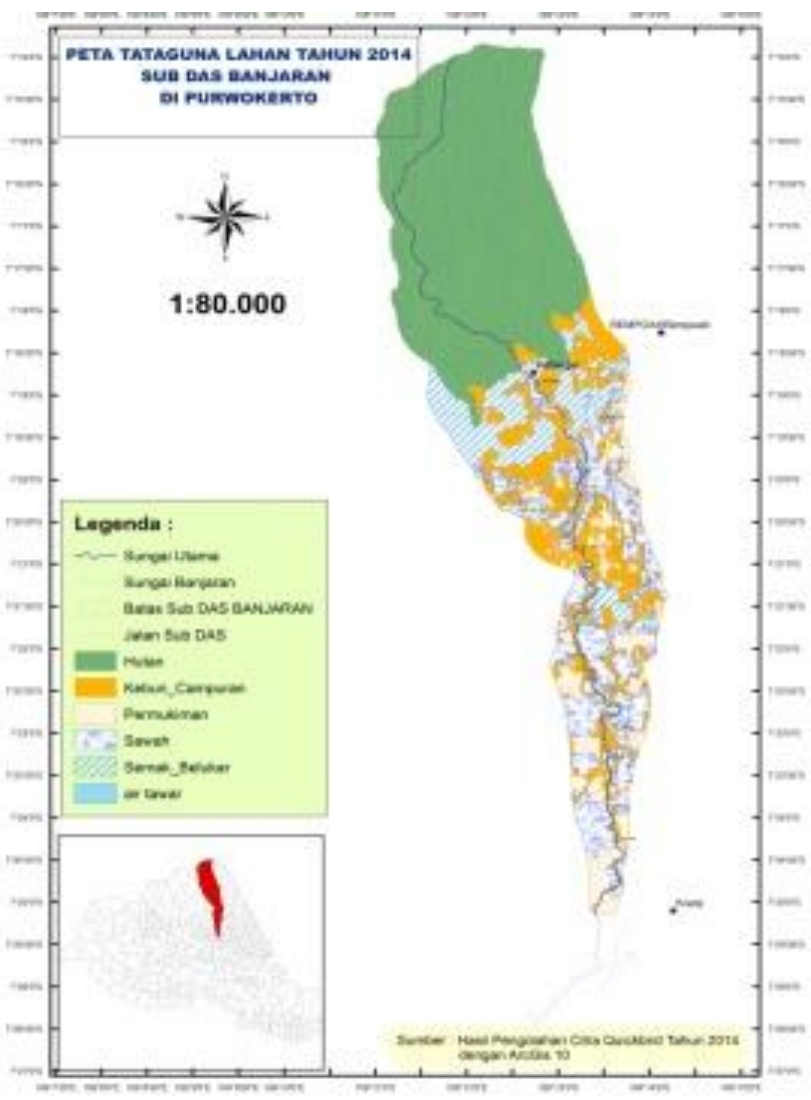

Gambar 3. Peta tataguna lahan tahun 2014

\subsection{Analisa RTRW}

Monitoring dan evaluasi kesesuaian penggunaan lahan (KPL) dimaksudkan untuk mengetahui kesesuaian penggunaan lahan dengan RTRW atau zona kelas kemampuan lahan dan yang ada di DAS. Pedoman yang digunakan untuk ini adalah indeks kesesuaian penggunaan lahan yang dikeluarkan oleh Departemen Kehutanan melalui Peraturan Dirjen Rehabilitasi Lahan dan Perhutanan Sosial Nomor P.04/V-SET/2009 tanggal 05 Maret 2009 tentang pedoman Monitoring dan Evaluasi DAS (Departemen Kehutanan, 2009).

Sub DAS Banjaran termasuk dalam kategori baik dengan nilai KPL diatas 75 persen, dimana berturut ketidaksesuaian tersebut tahun 2005 adalah 5,61\% (nilai $\mathrm{KPL}=94,39 \%$ ), tahun $20105,80 \%$ (nilai $\mathrm{KPL}=94,20$ $\%$ ) dan tahun 2014 sebesar 6,27 \% atau nilai KPL 93,73 $\%$.

\subsection{Debit Observasi}

Rating Curve dibuat berdasarkan data debit sungai Banjaran, yakni dari pencatatan debit harian/pengamatan tinggi muka air, yang dikonversikan menjadi debit sungai dari Pos Duga Air yang ada di Bendung Karangnangka. Dari hubungan ini (liku kalibrasi) digunakan untuk menentukan/mengubah menjadi besaran debit dengan mengetahui grafik tinggi muka air/hidrograf muka air yang biasa disebut dengan

Copyright @ 2017, TEKNIK, p-ISSN 0852-1697, e-ISSN: 2460-9919 


\section{Teknik, 38 (2), 2017, 123}

AWLR. Data debit di atas kemudian dibuat hitungan untuk membuat Rating Curve dan dihasilkan persamaan rating curve-nya adalah $\mathbf{Q}=\mathbf{1 1 , 3 8} \mathbf{X}^{\mathbf{2 , 6 2 7}}$. Grafik Rating Curvenya/liku kalibrasi dan profil penampang sungai disajikan pada Gambar 4.

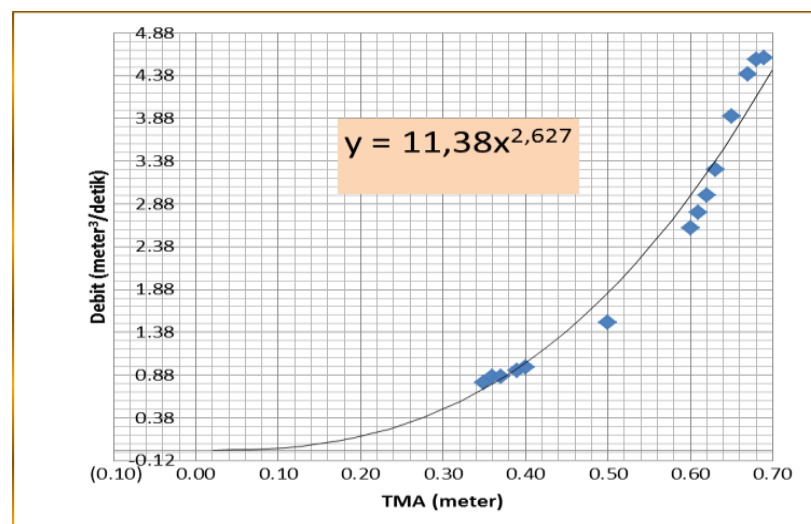

Gambar 4. Liku kalibrasi (Rating Curve) Sungai Banjaran di Bendung Karangnangka

\subsection{Debit Simulasi EPA-SWMM}

Berdasarkan hasil running pada program SWMM dengan memasukan semua parameter data yang dibutuhkan, maka hasil debit puncak banjir yang dihasilkan pada Junction 18 (Stasiun AWLR) adalah :hujan tanggal 28 Februari 2005 sebesar 23,51 $\mathrm{m}^{3} /$ detik, tanggal 28 Desember 2010 sebesar 30,92 $\mathrm{m}^{3} /$ detik, tanggal 14 April 2014 sebesar 115,71 m³/detik (Gambar 5).

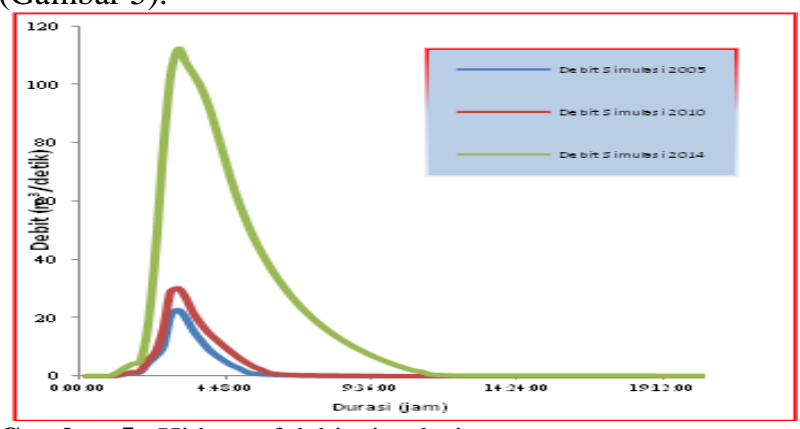

Gambar 5. Hidrograf debit simulasi

\subsection{Kalibrasi Model}

Dari hasil perhitungan kalibrasi dengan NASH dihasilkan nilai masing-masing untuk tahun 2005 performance rating memuaskan (satisfactory) atau 0,58 sedangkan untuk kalibrasi Nash tahun 2010 dan 2014 dihasilkan nilai performance rating sangat baik (very good) atau 0,86 dan 0,89 (Tabel 3). Secara umum hasil kalibrasi sangat baik dan mendekati nilai 1 (satu). Dengan demikian dapat disimpulkan model simulasi yang dihasilkan memenuhi kriteria yang dipersyaratkan dalam kalibrasi NASH (level performance criteria), sehingga model simulasi dengan EPA-SWMM ini dapat digunakan untuk simulasi model debit rencana selanjutnya. Rincian debit observasi dan debit simulasi dapat dilihat pada Gambar 6.

Tabel 3. Data hasil kalibrasi NASH

\begin{tabular}{cccccc}
\hline NO & TAHUN & $\begin{array}{c}\text { Qp.obs } \\
(\mathbf{m} / \mathbf{d t k})\end{array}$ & $\begin{array}{c}\overline{\mathbf{Q}} \mathbf{0 b s} \\
\left(\mathbf{m}^{3} / \mathbf{d t k}\right)\end{array}$ & $\begin{array}{c}\text { Qp. } \mathbf{s i m} \\
(\mathbf{m} / \mathbf{d t k})\end{array}$ & NASH \\
\hline 1 & 2005 & 27,54 & 6,59 & 23,51 & 0,58 \\
2 & 2010 & 40,41 & 36,70 & 30,92 & 0,86 \\
3 & 2014 & 113,49 & 76,13 & 115,71 & 0,89 \\
\hline
\end{tabular}

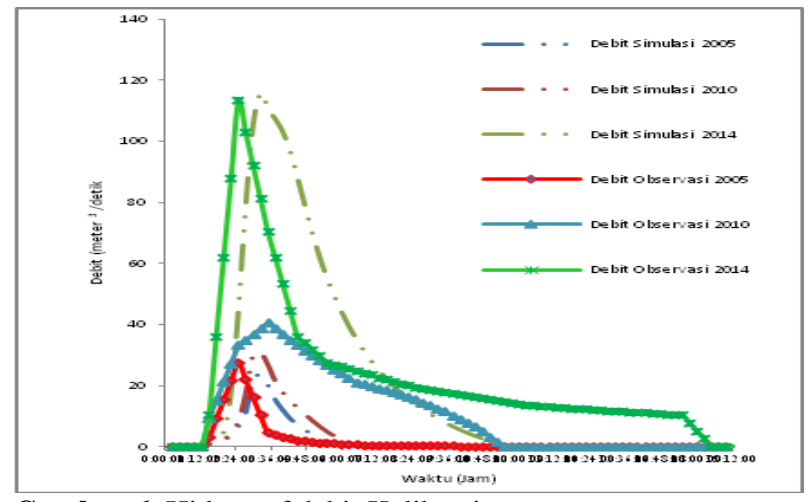

Gambar 6. Hidrograf debit Kalibrasi

Tabel 2. Hasil Perubahan Lahan 2005-2014

\begin{tabular}{|c|c|c|c|c|c|c|c|c|c|c|}
\hline \multirow{3}{*}{ No } & \multirow{3}{*}{$\begin{array}{c}\text { Tata Guna } \\
\text { Lahan }\end{array}$} & \multicolumn{3}{|c|}{ Luas Penggunaan Lahan } & & & \multicolumn{4}{|c|}{ Perubahan Tataguna Lahan } \\
\hline & & 2005 & 2010 & 2014 & \multicolumn{2}{|c|}{ 2002-2010 } & \multicolumn{2}{|c|}{$2010-2014$} & \multicolumn{2}{|c|}{$2005-2014$} \\
\hline & & Ha & Ha & Ha & На & Ha & Ha & Ha & Ha & Ha \\
\hline 1 & Hutan & 2314,95 & 2313,86 & 2323,28 & $-1,09$ & $-0,05$ & $-0,58$ & $-0,03$ & $-1,67$ & $-0,07$ \\
\hline 2 & Kebun campuran & 913,25 & 854,92 & 782,1 & $-58,33$ & $-6,39$ & $-72,82$ & $-8,52$ & $-131,15$ & $-16,77$ \\
\hline 3 & Sawah & 739,75 & 747,51 & 731,71 & $+7,76$ & $+1,05$ & $-15,8$ & $-2,11$ & $-8,04$ & $-1,10$ \\
\hline 4 & Semak Belukar & 399,55 & 447,02 & 530,02 & $+47,47$ & $+11,88$ & +83 & $+18,57$ & $+130,47$ & $+24,62$ \\
\hline 5 & Permukiman & 448,11 & 453,5 & 459,09 & $+5,39$ & $+1,20$ & $+5,59$ & $+1,23$ & $+10,98$ & $+2,39$ \\
\hline 6 & Air Tawar & 40,70 & 39,5 & 40,11 & $-1,2$ & $-2,95$ & $+0,61$ & $+1,54$ & $-0,59$ & $-1,47$ \\
\hline 7 & Jalan & 13,04 & 13,04 & 13,04 & 0 & 0 & 0 & 0 & 0 & 0 \\
\hline
\end{tabular}




\section{Teknik, 38 (2), 2017, 124}

\subsection{Penentuan Jenis Sebaran Cara Analisis}

Hasil perhitungan dispersi dibandingkan dengan dispersi persyaratan yang kemudian digunakan untuk memilih jenis sebaran yang dipakai sesuai dengan kriteria dalam pemilihan distribusi untuk daerah penelitian tercantum dalam Tabel 4.

Tabel 4. Penentuan jenis sebaran

\begin{tabular}{|c|c|c|c|c|c|c|}
\hline \multirow{3}{*}{$\begin{array}{c}\text { No } \\
1\end{array}$} & \multirow{3}{*}{$\begin{array}{c}\begin{array}{c}\text { Jenis } \\
\text { Distribusi }\end{array} \\
\text { Normal }\end{array}$} & \multicolumn{2}{|l|}{ Syarat } & \multicolumn{2}{|c|}{$\begin{array}{c}\text { Hasil } \\
\text { Perhitungan }\end{array}$} & \multirow{2}{*}{$\begin{array}{c}\begin{array}{c}\text { Keteranga } \\
\text { n }\end{array} \\
\text { Kurang }\end{array}$} \\
\hline & & $*) \mathrm{C}_{\mathrm{s}} \sim 0$ & & $\mathrm{C}_{\mathrm{s}}=$ & 0,382 & \\
\hline & & $*) \mathrm{C}_{\mathrm{k}} \sim 3$ & & $\mathrm{C}_{\mathrm{k}}=$ & 2,279 & Kurang \\
\hline & Gumbel & $\left.{ }^{*}\right) \mathrm{C}_{\mathrm{s}} \sim 1.1396$ & & $\mathrm{C}_{\mathrm{s}}=$ & 0,382 & Kurang \\
\hline 2 & Tipe 1 & $\left.{ }^{*}\right) \mathrm{C}_{\mathrm{k}} \sim 5.4002$ & & $\mathrm{C}_{\mathrm{k}}=$ & 2,279 & Kurang \\
\hline & & $*) \mathrm{C}_{\mathrm{s}}=\mathrm{C}_{\mathrm{v}}^{3}+3 \mathrm{C}_{\mathrm{v}}$ & $=0,109$ & $\mathrm{C}_{\mathrm{s}}=$ & 0,159 & Mendekati \\
\hline 3 & $\begin{array}{l}\text { Log } \\
\text { Normal }\end{array}$ & $\begin{array}{l}\left.{ }^{*}\right) \mathrm{C}_{\mathrm{k}}= \\
\mathrm{C}_{\mathrm{v}}^{8}+6 \mathrm{C}_{\mathrm{v}}{ }^{6}+15 \mathrm{C}_{\mathrm{v}}{ }^{4}+ \\
16 \mathrm{C}_{\mathrm{v}}{ }^{2}+3\end{array}$ & $=3,021$ & $\mathrm{C}_{\mathrm{k}}=$ & 2,139 & Mendekati \\
\hline & $\log$ & $*) \mathrm{C}_{\mathrm{s}} \neq 0$ & & $\mathrm{C}_{\mathrm{s}}=$ & 0,159 & Mendekati \\
\hline 4 & $\begin{array}{l}\text { Pearson } \\
\text { III }\end{array}$ & $* *) \mathrm{C}_{\mathrm{k}}=1,5 \mathrm{C}_{\mathrm{s}}^{2}+3$ & $=3,036$ & $\mathrm{C}_{\mathrm{k}}=$ & 2,139 & Kurang \\
\hline
\end{tabular}

Sumber : *) Triatmodjo, 2010, **) Sutiono et al., 1996

Dari perhitungan yang telah dilakukan di atas dengan syarat-syarat tersebut, maka dipilih distribusi yang paling mendekati yaitu distribusi Log Normal (Tabel 5).

Tabel 5. Curah hujan rencana dengan Log Normal

\begin{tabular}{ccccccc}
\hline No & Tahun & Xrt (mm) & S & $\begin{array}{c}\text { K Log } \\
\text { Normal }\end{array}$ & $\begin{array}{c}\text { Log Xt } \\
(\mathbf{m m})\end{array}$ & $\mathbf{X t}$ \\
\hline 1 & 2 & 2,138 & 0,078 & 0,000 & 2,138 & 137,37 \\
2 & 5 & 2,138 & 0,078 & 0,840 & 2,203 & 159,67 \\
3 & 10 & 2,138 & 0,078 & 1,280 & 2,237 & 172,75 \\
4 & 25 & 2,138 & 0,078 & 1,708 & 2,271 & 186,51 \\
5 & 50 & 2,138 & 0,078 & 2,050 & 2,297 & 198,28 \\
\hline
\end{tabular}

\subsection{Hasil Simulasi dan Usaha Pengendalian Banjir}

Hasil simulasi periode 2 hingga 50 tahun dapat dilihat pada Gambar 7, dengan rincian hasil simulasi scenario usaha pengendalian banjir pada Tabel 6. Tabel 6 menunjukkan bahwa dari beberapa metode pengendalian banjir yang paling efektif dilakukan adalah pembuatan sumur resapan. Hal ini karena beberapa alasan: dari segi anggaran lebih kecil dan usaha bisa dilakukan bersamasama dengan masyarakat, pelaksanaan bisa bertahap atau serentak, serta pemeliharaan tidak mahal dan dari segi penurunan debit cukup efektif.

\section{Kesimpulan}

\subsection{Kesimpulan}

1. Perubahan penggunaan lahan permukiman meningkat dari tahun 2005-2014 sebesar 10,98 ha (2,39 \%), penurunan luas hutan 1,67 ha $(0,07 \%)$, telah mengakibatkan kenaikan debit periode ulang 2 sampe dengan periode ulang 50 tahun. Periode ulang 2 tahun $3,08 \mathrm{~m}^{3} / \mathrm{dtk}(2,16 \%), 5$ tahun $3,5 \mathrm{~m}^{3} / \mathrm{dtk}(1,87 \%), 10$ tahun $3,72 \mathrm{~m}^{3} / \mathrm{dtk}(1,7 \%), 25$ tahun $3,94 \mathrm{~m}^{3} / \mathrm{dtk}(1,60$ $\%)$ dan 50 tahun $4,13 \mathrm{~m}^{3} / \mathrm{dtk}(1,50 \%)$, begitu juga dengan volume terjadi peningkatan : periode ulang 2 tahun $0,57 \%\left(10 \cdot 10^{6}\right)$ liter, periode ulang 5 tahun, $0,45 \%\left(12 \cdot 10^{6}\right)$ liter, untuk periode ulang 10 tahun $0,42 \%\left(13 \cdot 10^{6}\right)$ liter, untuk periode ulang 25 tahun dan $0,33 \%\left(12.10^{6}\right)$ liter dan periode ulang 50 tahun $0,35 \%\left(14.10^{6}\right)$ liter.

Tabel 6. Hasil simulasi berbagai skenario

\begin{tabular}{llcc}
\hline NO. & \multicolumn{1}{c}{ SKENARIO } & $\begin{array}{c}\mathbf{Q} \text { 25 } \\
\left(\mathbf{m}^{3} / \mathbf{d e t i k}\right)\end{array}$ & $\begin{array}{c}\mathbf{Q ~ 5 0} \\
\left(\mathbf{m}^{3} / \mathbf{d e t i k}\right)\end{array}$ \\
\hline 1 & Existing & 260,54 & 290,44 \\
2 & Penegakan Hukum & 247,73 & 276,01 \\
3 & Sumur Resapan & Tidak diperlukan & 259,26 \\
4 & RTRW 2031 & 237,18 & 264,14 \\
5 & Pembuatan Embung & 228,99 & 269,54 \\
6 & Penegakan Hukum dan & Tidak diperlukan & 244,52 \\
& Sumur Resapan & & \\
7 & Pembuatan Embung dan & Tidak diperlukan & 249,86 \\
\hline
\end{tabular}

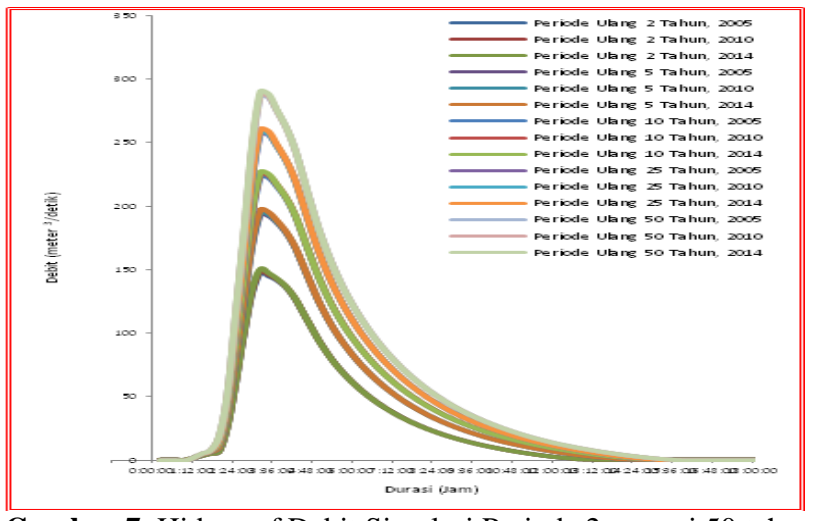

Gambar 7. Hidrograf Debit Simulasi Periode 2 sampai 50 tahun

2. Usaha pengendalian yang dilakukan meliputi penegakkan hukum dimana usaha ini mampu menurunkan debit $12,81 \mathrm{~m}^{3} / \mathrm{dtk}(4,9 \%) \mathrm{Q}_{25}$ tahun dan $14,43 \mathrm{~m}^{3} / \mathrm{dtk}(4,9 \%) \mathrm{Q}_{50}$ tahun, metode pembuatan embung mampu menurunkan debit $31,55 \mathrm{~m}^{3} / \mathrm{dtk}$ $(10,86 \%) \mathrm{Q}_{25}$ tahun dan $20,9 \mathrm{~m}^{3} / \mathrm{dtk}(7,1 \%) \mathrm{Q}_{50}$ tahun, metode sumur resapan mampu menurunkan debit $1,28 \mathrm{~m}^{3} / \mathrm{dtk}(0,49 \%) \mathrm{Q}_{25}$ tahun dengan $\mathrm{R}_{50 \text { tahun }}$, untuk skenario RTRW 2031 mampu menurunkan debit $23,36 \mathrm{~m}^{3} / \mathrm{dtk}(8,96 \%) \mathrm{Q}_{25}$ tahun dan $26,3 \mathrm{~m}^{3} / \mathrm{dtk}$ $(9,05 \%) \mathrm{Q}_{50}$ tahun, usaha dengan kombinasi sumur resapan dan penegakan hukum dengan $\mathrm{R}_{50}$ mampu menurunkan debit $16,02 \mathrm{~m}^{3} / \mathrm{dtk}(6,14 \%) \mathrm{Q}_{25}$ tahun dan $45,92 \mathrm{~m}^{3} / \mathrm{dtk}(15,81 \%) \mathrm{Q}_{50}$ tahun dan metode kombinasi pembuatan embung dan penegakan hukum dengan $\mathrm{R}_{50}$ mampu menurunkan debit $10,68 \mathrm{~m}^{3} / \mathrm{dtk}$ $(4,09 \%) \mathrm{Q}_{25}$ tahun dan 40,58 $\mathrm{m}^{3} / \mathrm{dtk}(13,97 \%) \mathrm{Q}_{50}$ tahun.

3. Berdasarkan nilai Kesesuaian Penggunaan Lahan (KPL) Sub DAS Banjaran termasuk dalam kategori baik dengan nilai KPL diatas 75 persen, dimana 


\section{Teknik, 38 (2), 2017, 125}

berturut ketidaksesuaian tersebut tahun 2005 adalah 5,61\% (nilai KPL = 94,39\%), tahun 2010 .

4. Penggunaan Citra Satelit QuickBird dengan resolusi yang tinggi sangat tepat digunakan untuk analisa tataguna lahan khususnya penentuan area impervious dan pervious dalam perhitungan banjir dengan EPA$S W M M$, hal ini berkaitan dengan ketelitian dalam penentuan daerah impervious dan pervious.

\subsection{Saran}

1. Pemerintah Kabupaten Banyumas menerapkan secara tegas aturan-aturan hukum berkenaan tata ruang dan pelanggaran sempadan sungai.

2. Stakeholder ikut berkontribusi dalam pelestarian lingkungan Sub DAS Banjaran, diantaranya membuat sumur-sumur resapan secara komunal, penanaman pohon konservasi, dan cara-cara lain yang bertujuan menjaga kelestarian DAS.

3. Perlu adanya penelitian tentang pengaruh perubahan tataguna lahan terhadap banjir banjir berbasis penginderaan jauh dengan membandingkan beberapa metode yang lebih bervariatif.

\section{Daftar Pustaka}

Abadi Purwa Citra. (2009). Laporan Status Lingkungan Hidup Daerah Kabupaten Banyumas Tahun 2009. Purwokerto.
Departemen Kehutanan (2009). Peraturan Dirjen Rehabilitasi Lahan dan Perhutanan Sosial Nomor P.04/V-SET/2009 tanggal 05 Maret 2009 tentang pedoman Monitoring dan Evaluasi DAS. Jakarta: Departemen Kehutanan.

Dienaulie, A. (2011). Pengaruh Pembangunan Hotel Imperium Aston Terhadap Perubahan Harga Lahan Di Pusat Kota Purwokerto, Skripsi. Fakultas Teknik, Jurusan Perencanaan Wilayah dan Kota, Universitas Diponegoro.

Moriasi, D.N., Arnold, J.G., Van Liew, M.W., Binger, R.L., Harmel, R.D., and Veith, T.L. (2007). Model Evaluation Guidelines for Systematic Quantification of Accuracy in Watershed Simulations. Transactions of the ASABE, 50(3), 885-900.

Pikiran Rakyat. (2009). Ratusan Rumah di Purwokerto Terendam Banjir. Tersedia di http://www.pikiranrakyat.com/nasional/2009/06/04 190700/ratusan-rumah-di-purwokerto-terendam banjir. Diakses 11 Desember 2015.

Suripin (2004). Sistem Drainase Perkotaan yang Berkelanjutan. Yogyakarta: Penerbit Andi.

Suroso, Susanto, H.A. (2006). Pengaruh Perubahan Tataguna Lahan Terhadap Debit Banjir Daerah Aliran Sungai Banjaran. Jurnal Teknik Sipil Universitas Jenderal Soedirman. 3(2), 75 - 80.

Triatmodjo, B. (2010). Hidrologi Terapan. Yogyakarta: Beta Offset. 